\title{
Breeding dispersal movements of Dupont's Lark Chersophilus duponti in fragmented landscape
}

\author{
CRISTIAN PÉREZ-GRANADOS* (D), PEDRO SÁEZ-GÓMEZ (D) and \\ GERMÁN M. LÓPEZ-IBORRA (D) \\ Ecology Department/IMEM “Ramón Margalef", Universidad de Alicante, o3080, Alicante, \\ Spain.
}

*Author for correspondence; email: cristian.perez@ua.es

(Received 21 April 2020; revision accepted 11 February 2021)

\begin{abstract}
Summary
Understanding patterns of dispersal behaviour of threatened species is important in conservation biology and population ecology, especially in fragmented landscapes. Dupont's Lark Chersophilus duponti is a threatened passerine whose European population has declined by around $40 \%$ in the last decade. To study natal and breeding dispersal of the species, we used a long-term mark-recapture dataset (2011-2019) and analysed the records of 32 males (39 dispersal movements) and five females (five dispersal movements) captured during the breeding season at Rincón de Ademuz (Valencia, eastern Spain). Adult birds had a median breeding dispersal of $154 \mathrm{~m}\left(\mathrm{Q}_{25}-\mathrm{Q}_{75}=70.0-300.3\right)$. Among these captures, two adult males dispersed to a new patch of habitat separated by more than $5,800 \mathrm{~m}$. Only one out of 26 nestlings ringed was trapped as an adult bird, which occurred at a site different from the natal territory $(4,500 \mathrm{~m})$. Our results show a low breeding dispersal for the species and are, in essence, in agreement with previous studies carried out in the Ebro Valley metapopulation, one of the core areas for the species in Europe. Nonetheless, unlike in the Ebro Valley, we detected movements of adult birds between habitat patches. The low recovery rate of young birds suggests that they left their natal sites and moved outside the study area or that their survival rate was very low. Future studies focused on the post-fledging survival rate and natal dispersal movements are essential to determine effective conservation measures for the species. Habitat management actions in occupied and potential sites should be carried out close to the areas inhabited by the species to increase the success rate of the interventions and the effective dispersal and therefore population connectivity.
\end{abstract}

Keywords: Alaudidae, mark-recapture, site-fidelity, spatial ecology, territory.

\section{Introduction}

Animal dispersal is a key life-history trait related to gene flow, demography, and social evolution of wildlife populations (Lidicker 1975, Taylor and Taylor 1977, Baguette et al. 2013, Aguillon et al. 2017). Consequently, understanding patterns of dispersal is essential in conservation biology, population ecology and biogeography, as it provides basic information to assess long-term persistence of populations in fragmented landscapes and therefore their conservation status (Baillie et al. 2002, Caplat et al. 2016, Legrand et al. 2017). Two main types of dispersal movements have been 
traditionally described: natal and breeding dispersal. Natal dispersal can be defined as the movement of juveniles from their natal territory to their first breeding site, while breeding dispersal is the movement of already established adults between breeding sites in successive years (Greenwood 1980, Greenwood and Harvey 1982).

Usually, natal dispersal has a greater impact on populations than breeding dispersal (but see Dale et al. 2005) due to its higher frequency (number of individuals dispersing) and magnitude (dispersal distances) (Greenwood and Harvey 1982, Paradis et al. 1998). In fact, most avian dispersal studies have determined very low breeding dispersal, and a tendency to breed in the same area in successive years (e.g. Greenwood and Harvey 1982, Paradis et al. 1998, Aguillon et al. 2017). However, there is a large number of factors that may influence whether an individual performs a short dispersal or seeks out a new site, such as sex (females usually disperse farther than males, Greenwood and Harvey 1982, Aguillon et al. 2017) and sexual system (mate-site fidelity; Cézilly et al. 2000), among others. The importance of these factors in selecting for dispersal may vary between species and populations according to their life history and how they interact with the environment. Due to the strong link between dispersal and population dynamics, knowing the dispersal movements is essential for population management and for understanding how species will respond to habitat changes and management actions. This is particularly important in species with low dispersal ability and therefore vulnerable to landscape transformation (i.e. habitat fragmentation).

Dupont's Lark Chersophilus duponti is a territorial resident passerine restricted to Spain and North Africa (Suárez 2010), whose European population is made up of about 1,300-2,400 breeding pairs (Suárez 2010). In Spain, the species has experienced overall a 41\% decline from 2004 to 2015 (Gómez-Catasús et al. 2018) and it is listed as 'Vulnerable' by IUCN (BirdLife International 2020). Because of its cryptic colour and elusive behaviour, obtaining data on dispersion is a challenge for researchers and managers (but see Laiolo et al. 2007, Vögeli et al. 2008). Prior research in the Ebro Valley metapopulation (north-eastern Spain), one of the strongholds for the species in Europe (Suárez 2010, Vögeli et al. 2010), revealed very short breeding dispersal of Dupont's Lark males with no detected movements between patches of suitable habitat (median values of 75 and $113 \mathrm{~m}$ for capture-recapture and acoustic marking, respectively; Laiolo et al. 2007, Vögeli et al. 2008). This is in agreement with the low dispersal ability and low gene flow described in other studies (García et al. 2008, Vögeli et al. 2010, Méndez et al. 2011). Although natal dispersal of the species is unknown, it has been proposed that the species may be reluctant to leave the natal site when faced with dispersal through hostile habitat (Laiolo and Tella 2007). However, a record of an immature male moving up to $33 \mathrm{~km}$ has been reported in the Iberian System in central Spain (García-Antón et al. 2015). Likewise, there are some observations of wintering individuals of unknown age hundreds of kilometres away from the closest known populations (Suárez et al. 2006), which suggests that the potential of the species for dispersal might be greater than expected. Due to the apparent dispersal limitations of the adult males (Vögeli et al. 2010), studies focused on the dispersal behaviour of Dupont's Lark may have great relevance for assessing long-term persistence of their populations, and in improving habitat management actions, which have been performed in many potential habitat patches (Palma 2018, Pérez-Granados and Traba 2019, authors' unpubl. data).

In this work, we aimed to: (I) estimate, based on capture-recapture data, the breeding dispersal of Dupont's Lark in the Valencian metapopulation (eastern Spain) including, for the first time, data on female movements and the first case of natal dispersal; and (2) compare our results, from small populations in a fragmented landscape (see study area), with those obtained by Laiolo et al. (2007) in the Ebro Valley, the second stronghold for Dupont's Lark in Spain (around 400 male territories; Laiolo et al. 2007). We predicted that Dupont's Lark movements in the Valencian metapopulation would be lower than in the Ebro Valley owing to the smaller patch sizes, and therefore movement limitations, in Valencia (see Table 1 ). 
Table 1. Characteristics of the Dupont's Lark metapopulation of Ademuz and of the Ebro Valley. Data are shown only from occupied patches. Total number of males (and mean density) in Ademuz refers to the minimum and maximum detected during the study period. Data for Ademuz were extracted from PérezGranados and López-Iborra (2013) and authors' unpublished data, while data from the Ebro Valley were extracted from Vögeli et al. (2010).

\begin{tabular}{lcc}
\hline & Ademuz & Ebro Valley \\
\hline Number of patches & 5 & 40 \\
Mean patch size (ha) (range) & $152.1(59-199)$ & $189.4(3.7-1006.3)$ \\
Number of patches $>$ 200 ha & 0 & 12 \\
Number of males & $46-56$ & 680 \\
Mean density (males/1oha) & $0.60-0.73$ & 1.37 \\
Mean distance to the nearest patch $(\mathrm{km})$ (range) & $0.77(0.05-2.12)$ & $5.25(1-24.1)$ \\
\hline
\end{tabular}

\section{Material and methods}

\section{Study area}

The study was carried out between mid-March and mid-June 2011-2019 in Rincón de Ademuz, located in the southern extreme of the Iberian System (Valencia province, eastern Spain, $40^{\circ} \mathrm{O}^{\prime} \mathrm{N}$, $\mathrm{OI}^{\circ} 2 \mathrm{O}^{\prime} \mathrm{W}$; Figure I). This metapopulation covered the entire known distribution range of Dupont's Lark in Valencia province (Pérez-Granados and López-Iborra 2013). Dupont's Larks occurred in five closely and patchily distributed sites, but eight other potentially suitable habitat sites, three of them abandoned recently, were surveyed annually (Pérez-Granados and López-Iborra 2013; Figure 1). The metapopulation suffered an annual decline of around 10\% between 2004 and 2011 (Pérez-Granados and López-Iborra 2013), but remained stable during the study period (population size ranged from 46 to 56 males; authors' unpubl. data). Previous studies found that the density of the species in the Iberian System increases as the area of the habitat patches shrinks (Pérez-Granados and López-Iborra 2013), which has been related to the existence of dispersal limitations (Vögeli et al. 2010). Maximum distance among patches (i.e. populations) is $2.1 \mathrm{~km}$ (Figure I), which is within the maximum distance of movements recorded for the species (Laiolo et al. 2007, García-Antón et al. 2015). Occupied patches averaged $152 \pm 62$ ha (mean $\pm \mathrm{SE}$ ) in size (range 59-199 ha).

The study area is located at $1,100 \mathrm{~m}$ asl and is characterized by a flat topography dominated by areas dedicated to crops, especially almond trees Prunus dulcis, or scrub. Vegetation at all monitored sites was dominated by low shrub species (Genista scorpius, Rosmarinus officinalis and Thymus spp.), with some scattered trees, especially junipers Juniperus thurifera and pines Pinus spp. Mean annual temperature was about $10^{\circ} \mathrm{C}$ and mean annual precipitation around $550 \mathrm{~mm}$ (see Pérez-Granados et al. 2017a for a detailed description of the study area).

\section{Field procedures}

Data collection was based on a census mapping method (Pérez-Granados and López-Iborra 2017), nest-monitoring and ringing sessions (Pérez-Granados et al. 2017b). Unoccupied sites were surveyed three times per breeding season and no individuals were detected. Occupied sites were visited eight or nine times every breeding season with a regular periodicity (usually one visit every Io days) during the study period. On each visit we performed a dawn survey, during which we georeferenced the location of singing males (territory hereafter) with the aid of a GPS (Garmin eTrex legend $\mathrm{HCx}$ ). To capture and mark the individuals, we placed 3-4 small spring-traps close to the location where vocalizing males were detected during the dawn survey. Each day we placed spring-traps in 3-4 different territories. Spring-traps were baited with tenebrionids and a playback equipment $\left(\mathrm{MP}_{3}\right.$ and Radioschack amplifier) was used to attract birds into traps. We set traps in 


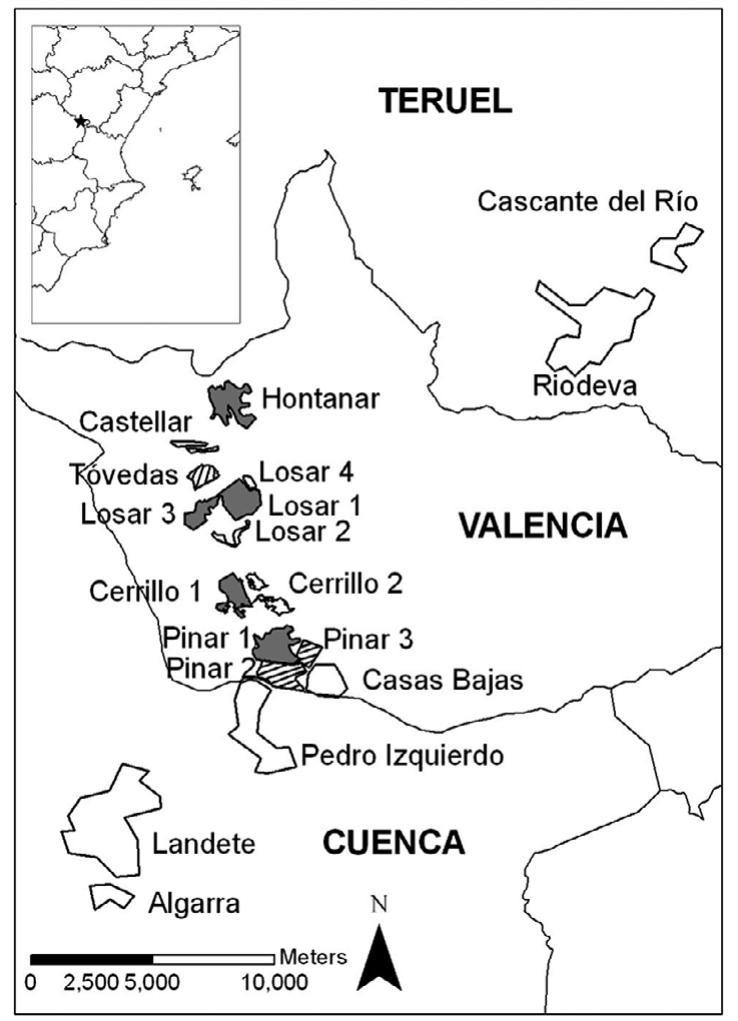

Figure 1. Location of the potential habitat patches surveyed (polygons within Rincón de Ademuz, Valencia province). Occupied patches are painted in grey and three extinct patches are marked with black stripes. Location of the closest Dupont's Lark populations in the provinces of Cuenca and Teruel is also shown. Inset shows the location of the study area in Spain.

every identified Dupont's Lark territory, at least three times per year. The location of the traps varied between years according to the changes in the location of the territories (i.e. singing males), and even within years according to singing male location. Similarly, we also searched intensively for colour-ringed individuals three times per year in every territory. Whenever possible, we trapped and ringed adult birds at the nest $(n=16)$ using a passive trap (females) or spring-traps (Pérez-Granados et al. 2017b). To facilitate reading, trap and nest captures (and recaptures) and resightings of colour-ringed individuals were all considered as part of physical marking (Vögeli et al. 2008).

Captures were performed during the first four hours after dawn on days with good weather conditions (no rain, mist, or strong winds). Trapped birds were ringed with a combination of one metal ring and up to three colour rings to allow individual identification at a distance. With the exception of nestlings, all trapped birds were aged as adults (birds born earlier than the current breeding season) since they cannot be differentiated from older birds after their complete moult cycle (Svensson 1992), which takes place during the post-breeding period. Adult birds were sexed according to the presence of brood patches (females), cloacal protuberances (males) or wing length (males > $97 \mathrm{~mm}$; Vögeli et al. 2007, Suárez 2010). Nestlings were ringed at the nest, but no sex identification was possible at the time of ringing. The locations of the trappings or sightings were georeferenced using a GPS (Garmin eTrex legend HCx). 


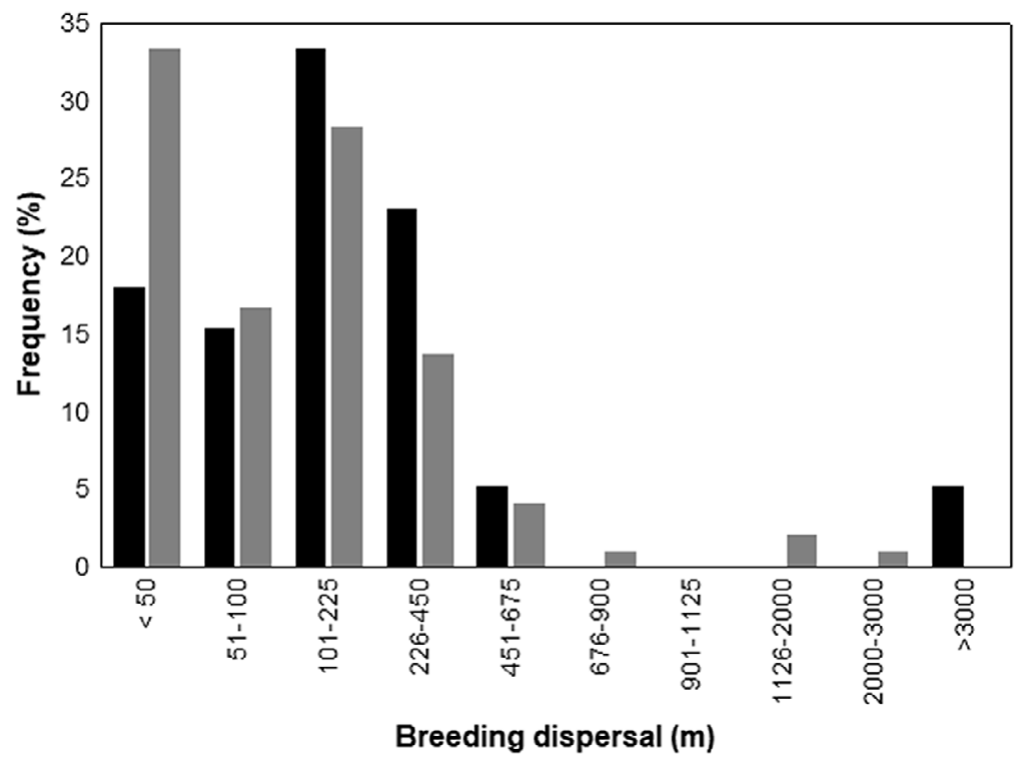

Figure 2. Distribution of breeding dispersal distances recorded for adult Dupont's lark males in the study area (black bars) and in the Ebro Valley (grey bars). Data for the Ebro Valley based on Laiolo et al. (2007).

\section{Dispersal estimation}

We used the Euclidean distance between the locations of recaptured birds in successive years as a surrogate of the dispersal movements of the species (see Nathan et al. 2012). Distances were calculated using ArcMap software, ArcGis 10.I (ESRI, Redlands, CA, USA). When the same bird was recaptured in more than two different years (six individuals), we measured the distance between each pair of years and treated each distance as independent data. Five birds were trapped more than once during the same breeding season, always within a radius of $150 \mathrm{~m}$. In these cases, we selected only the first position on subsequent analyses, since the peak of the breeding season of the species in the study area occurs during the first month of the monitoring programme (midApril; Pérez-Granados et al. 2017b).

\section{Statistical analyses}

We estimated the recovery rate of ringed adults and nestlings as the proportion of ringed birds that were recaptured in the subsequent seasons. We tested for possible differences in breeding dispersal distances between Dupont's Lark males from our study area ( $n=32$ males, 39 recaptures) and those reported for the Ebro Valley metapopulation (Laiolo et al. 2007). For this purpose, we used the dataset collected in the Ebro Valley provided by Paola Laiolo. This dataset contained the breeding dispersal distances of 70 males recaptured by physical recapture and 128 males resighted based on voice recognition (see details in Laiolo et al. 2007). Laiolo et al. (2007) stated that the two methods provided similar displacement distances, with no significant differences among them. On this basis, we combined both data sets to obtain a complete data set for the Ebro Valley $(n=198)$. Because these data were not distributed normally (Figure 2 and Laiolo et al. 2007), differences in breeding dispersal distances between the two areas were analysed using a Mann-Whitney $\mathrm{U}$ test. In addition, for each study area (Ademuz and Ebro Valley) we estimated the probability density distribution of recapture distances (dispersal location kernel, sensu Nathan et al. 2012) using the Gaussian kernel 
algorithm implemented in the "density" function in R ( R Development Core Team 2017). This distribution was then numerically integrated to obtain the probability of staying within or moving between distance intervals equivalent to the average diameter of a territory. We defined a territory as the 4-ha area, which is the mean core area estimated for Dupont's Lark males during the breeding season (Garza et al. 2005). This territory size corresponds to a circle $225 \mathrm{~m}$ in diameter, a distance that is very similar to the territory-switch threshold used by Laiolo et al. (2007). Therefore, we calculated the probability of recapturing a male within a distance of $225 \mathrm{~m}$ (staying in the same territory), moving one territory (recapture between 226 and $500 \mathrm{~m}$ ) and so on. All statistical analyses were performed in R 3.4.I (R Development Core Team 2017), and the level of significance was $P<0.05$.

\section{Results}

A total of 120 adult ( 93 males, 27 females) and 26 nestling Dupont's Larks were ringed during the study period. In subsequent years, we recaptured 32 males (male recovery rate $=34.4 \%$ ) and 4 females (female recovery rate $=14.8 \%$ ) corresponding to a total of 44 breeding dispersal movements, but only one bird ringed as nestling (nestling recovery rate $=3.8 \%$ ). Adult Dupont's Larks had a median breeding dispersal of $154 \mathrm{~m}$ (range $14-5,837, \mathrm{Q}_{25}-\mathrm{Q}_{75}=70.0-300.3$; Figure 2). Considering only males, median breeding dispersal was $156.6 \mathrm{~m}$ (range $14-5,837, \mathrm{Q}_{25}-\mathrm{Q}_{75}=$ 69.0-300.6), while females had a median breeding dispersal of $151.5 \mathrm{~m}$ (range 43-416, Q25-Q75 = 71.0-250.0). Two adult males were recaptured in different patches; both were ringed in Pinar 1 and recaptured in Losar 1 after one and three years at distances of 5,828 and 5,873 m, respectively. The only nestling recaptured as an adult was detected in a habitat patch (Losar 1 ) different from the natal site (Hontanar), at a distance of 4,503 $\mathrm{m}$, the year after birth. This bird was sexed as female when recaptured based on wing length $(95 \mathrm{~mm})$ and the presence of a brood patch.

Breeding dispersal distances of Dupont's Lark males differed significantly between our study area and the Ebro Valley (Mann-Whitney $U$ test, $\mathrm{z}=-2.67, P=0.008$ ). Adult males from the Ebro Valley showed a shorter median breeding dispersal (101.2 m, range O-2193, Q25-Q75=8.0200.0), than males in our study area ( $154.0 \mathrm{~m}$, range $14-5837, \mathrm{Q}_{25}-\mathrm{Q}_{75}=70.0-300.3$ ). This significant difference remained even when the two males recaptured in different patches in Ademuz were excluded from the analysis (Mann-Whitney $U$ test, $z=-2.23, P=0.026$ ). The probability of remaining in the same territory was higher in the Ebro Valley (0.78) than in the study area (0.63), while the probabilities of moving the distance equivalent to one or two territories were lower in the Ebro Valley (0.13 and 0.04, respectively) than in Valencia (0.26 and 0.05, respectively). On the contrary, the probability of dispersing the equivalent distance to between three and 1o territories was higher in the Ebro Valley (0.04) than in our study area (0.005) (Figure 3). In the Ebro Valley, no birds were retrapped further than 2,200 $\mathrm{m}$ away, and therefore the probability of dispersing further than 1o territories was 0 , while in our study area this probability was 0.05 (Figure 3).

\section{Discussion}

The present study provides the first information on breeding dispersal distance of the Dupont's Lark for each sex and the only known case of natal dispersal. Our findings are consistent with a previous study carried out in the Ebro Valley metapopulation (Laiolo et al. 2007, Vögeli et al. 2008), a less fragmented landscape than our study area. In both areas analysed, adult males showed high fidelity to remain in their breeding territories or to carry out reduced breeding dispersal movements, equivalent to a territory size (joint probability of staying or moving one territory: $90-92 \%$ in both areas). However, the differences in the landscape configuration among metapopulations may explain some of the differences found in inter- and intra-patch scale movements (Table 1 ). One of the main differences was detected in the probability of dispersing beyond $900 \mathrm{~m}$ (i.e. four territories), which was null in our study area and low, but constant, in the Ebro Valley (Figure 3). 


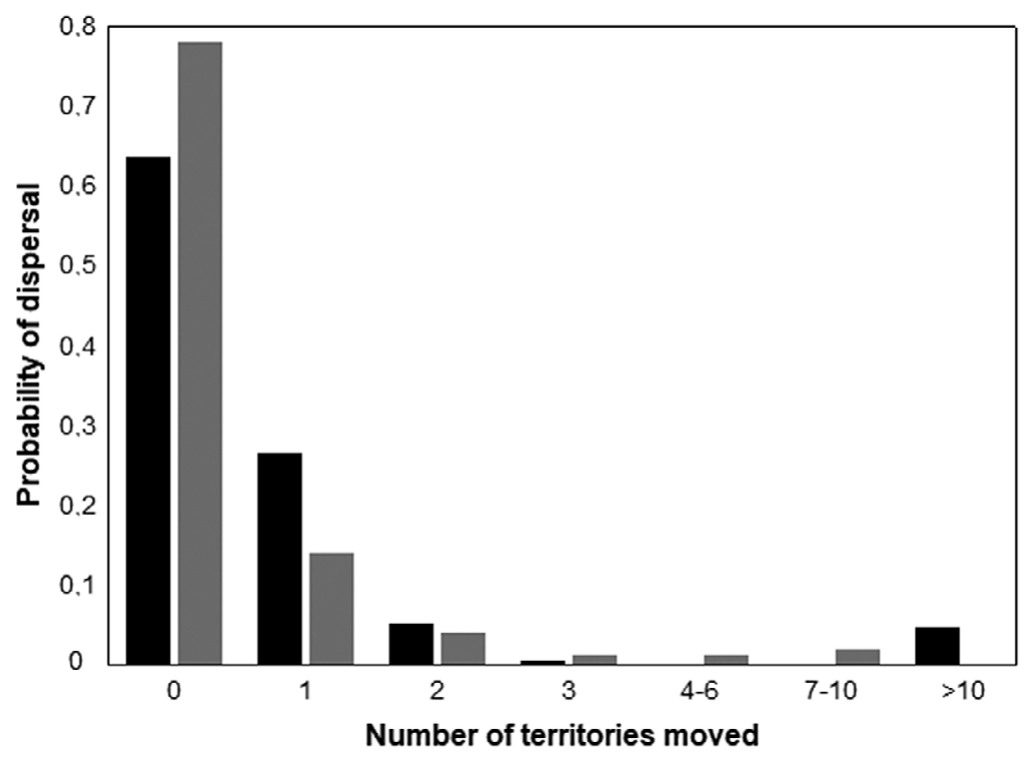

Figure 3. Probability of dispersing a variable number of territories by adult Dupont's lark males in the study area (black bars) and in the Ebro Valley (grey bars). Data for the Ebro Valley based on Laiolo et al. (2007).

Occupied patches in Ademuz averaged 152 ha (largest diameter $<1.3 \mathrm{~km}$ ) and so dispersal movement further than 4-5 territories within a patch is not possible. In contrast, in the Ebro Valley, $32 \%$ of the occupied habitat patches are larger than 150 ha and host $70 \%$ of the breeding population (Vögeli et al. 2010), thus allowing Dupont's Lark males to make longer intra-patch dispersal movements. The larger patch size could explain why movements of adults between patches were not detected in the Ebro Valley, despite the larger numbers of males and of patches within that metapopulation (Table 1 ). In a later study, nine males were classified as immigrants by acoustic marking in the Ebro Valley (maximum dispersal of $20 \mathrm{~km}$, Vögeli et al. 2010). However, as the age of these immigrants is unknown, it is not possible to classify these immigrants as cases of breeding or natal dispersal.

In the same way, population density (closely related to patch-habitat size; Vögeli et al. 2010) may play an important role in breeding dispersal movements of the species. Most patches of the Ebro Valley are larger than $200 \mathrm{ha}$, where density is half or one third that of smaller patches (Vögeli et al. 2010). The same pattern has been described in the Iberian System, where our study area is located (Pérez-Granados and López-Iborra 2013). All habitat patches in Ademuz are smaller than 200 ha and showed high densities (Pérez-Granados and López-Iborra 2013). Therefore, high density in Ademuz may result in increased competition among males to occupy the best sites for breeding and consequently increase the pressure for breeding dispersal. Indeed, there is evidence of high intraspecific competition in Ademuz, with a known case of clutch failure due to agonistic behaviour at a nest located in an area with high male density (five males ringed within a radius of $150 \mathrm{~m}$ around the nest during the same breeding season, Pérez-Granados and López-Iborra 2015). This pattern suggests a density-dependent breeding dispersal process where males located in highdensity populations might be more likely to disperse (within or between patches; Matthysen 2005). Although we have no proper data about the sex ratio of the species in the monitored metapopulation it is likely that a large proportion of adult males in Ademuz may remain unpaired during the breeding season, according to the known male-biased ratio for the species in other three areas (range 0.61-0.79\% of males, Vögeli et al. 2007; Suárez et al. 2009). Nonetheless, the presence of 
unpaired males does not necessarily reduce the competition among males. Indeed, a considerable fraction of floaters may increase territorial behaviour and competitive mate guarding of territorial males (reviewed by Penteriani et al. 2011 and Moreno 2016).

Another non-exclusive process that may explain the long movements registered in our study area is the decline of male numbers in the Pinar I patch, possibly caused by loss of habitat quality due to expansion of pines (Pinus spp.). Both cases of inter-patch dispersal movements involved males that moved from Pinar 1, where the decline is intense ( 13 males in 2011 to two in 2019, SáezGómez et al. 2019), towards the habitat patch with the largest number of males (Losar 1: 12 males in 2011 to 19 in 2019, Sáez-Gómez et al. 2019), located $5 \mathrm{~km}$ away. Due to the male-biased ratio in Dupont's Lark (Vögeli et al. 2007; Suárez et al. 2009), it is possible that males in smaller populations could fail more often in attracting a female and thus make longer-distance movements looking for mates (Dale et al. 2005). Further research is needed to assess the importance of both mechanisms (density-dependent dispersal and movements from declining sites) in determining breeding dispersal in this species.

The only nestling later recaptured as an adult was detected at a distance of 4,503 m). The low recapture rate of birds ringed as juveniles $(3.8 \%)$, when compared to adults $(30 \%)$, and a prior record of an immature bird (ringed with juvenile plumage in mid-September) moving further than $33 \mathrm{~km}$ (García-Antón et al. 2015), suggest that a high proportion of immatures may perform long dispersal movements between sites. The high density in the habitat patches surveyed may force juveniles to disperse through unfavourable habitat to establish a territory, which may partly explain the lower recapture rate detected for juvenile birds in our study. Under these circumstances, their survival probabilities may be compromised when dispersing and/or using marginal habitats. However, our results should be taken with caution since only one bird ringed as a nestling was recaptured and we have no data about post-fledging mortality neither about the survival of immatures during their first year, which may have had a considerable impact (e.g. Naef-Danzer et al. 2001, Cox et al. 2014, Shitikov et al. 2020). Although the adult recovery rate (30\%) may also seem low it is arguably related to the difficulty of trapping that elusive bird species. Using capturemark-recapture models we estimated the probability of recapture of adult males present at the study area during the breeding season as 0.31 , while we did not find any evidence of transients (Pérez-Granados et al. in prep). This value supports that the apparently low percentage of adults recaptured is related to the difficulty for trapping the species rather than to breeding dispersal movements outside the study area.

The dispersal movements presented here are a novel contribution to the knowledge of this threatened species but also one of the few studies describing detailed inter-annual movements in the Alaudidae (but see Delius 1965, de Juana et al. 2004, Wolf et al. 2020). Our results corroborate low breeding dispersal for Dupont's Lark but show that some birds may move between sites. This is in agreement with recent records of birds recaptured at distances of $20-33 \mathrm{~km}$ (Vögeli et al. 2010, García-Antón et al. 2015) and the detection of wintering Dupont's Larks at distances further than $100 \mathrm{~km}$ from the closest known breeding populations (Suárez et al. 2006). Overall, we are aware that our results are based on small sample sizes but believe that they improve our knowledge adequately on the breeding dispersal pattern of the species, with the exception of some long movements outside the studied areas, which may have been undetected. Further research should focus on increasing the number of known natal dispersal movements and performing detailed studies of post-fledging survival and breeding dispersal movements using GPS technology. The effectiveness of habitat management actions at potential sites, such as tree removal, promotion of extensive grazing and scrub clearance, designed to facilitate dispersal movements and increase population connectivity in fragmented landscapes would benefit from better knowledge on the dispersal processes of the species. Therefore, based on our results, conservation interventions aimed at increasing the habitat available to maintain larger populations or to improve habitat quality for the species (Palma 2018, Pérez-Granados and Traba 2019) would have greater probability of success if performed within a $1-\mathrm{km}$ radius of areas already occupied by the species, since adult birds rarely disperse further than that distance (Laiolo et al. 2007). 


\section{Acknowledgements}

This study was supported by Levantina y Asociados de Minerales, S.A., as part of the project "Estudios de investigación aplicados a la conservación de las poblaciones de alondra ricotí (Chersophilus duponti) en el entorno del municipio de Vallanca". We wish to thank the Servicio de Vida Silvestre of Conselleria D’infraestructures, Territori i Medi Ambient (Generalitat Valenciana) for ringing permits and supporting our work. We are grateful to Paola Laiolo, Matthias Vögeli, David Serrano and José Luis Tella for sending us their original dataset about dispersal distances of Dupont's Lark in the Ebro Valley. We thank Alberto Lucas for his collaboration with the project and Carlos Ponce for his collaboration with bird ringing. We also thank two anonymous referees and Paul Donald whose helpful comments contributed to improving the paper. Finally, we thank Nieves Herrero-García, Juancho Calleja, Beatriz Vigalondo and Eva Serrano-Davies for their help. Our methodology complies with current Spanish laws in the matter of avifauna capture and the three authors were authorized for ringing activities.

\section{References}

Aguillon, S. M., Fitzpatrick, J. W., Bowman, R., Schoech, S. J., Clark, A. G., Coop, G. and Chen, N. (2017) Deconstructing isolationby-distance: The genomic consequences of limited dispersal. PLoS Genet. 13: e1006911.

Baguette, M., Blanchet, S., Legrand, D., Stevens, V. M. and Turlure, C. (2013) Individual dispersal, landscape connectivity and ecological networks. Biol. Rev. 88: 310-326.

Baillie, S. R., Sutherland, W. J., Freeman, S. N., Gregory, R. D. and Paradis, E. (2002) Consequences of large-scale processes for the conservation of bird populations. J. Appl. Ecol. 37: 88-102.

BirdLife International (2020) Chersophilus duponti. The IUCN Red List of Threatened Species 2020: e.T22717380A173711498. Downloaded on 4 February 2021.

Caplat, P., Edelaar, P., Dudaniec, R. Y., Green, A. J., Okamura, B., Cote, J., Ekroos, J., Jonsson, P. R., Löndahl, J., Tesson, S.V.M. and Petit, E. J. (2016) Looking beyond the mountain: Dispersal barriers in a changing world. Front. Ecol. Env. 14: 261-268.

Cézilly, F., Dubois, F. and Pagel, M. (2000) Is mate fidelity related to site fidelity? A comparative analysis in Ciconiiforms. Anim. Behav. 59: 1143-1152.

Cox, W. A., Thompson III, F. R., Cox, A. S. and Faaborg, J. (2014) Post-fledging survival in passerine birds and the value of post-fledging studies to conservation. J. Wildl. Manage. 78: 183-193.
Dale, S., Lunde, A. and Steifetten, Ø. (2005) Longer breeding dispersal than natal dispersal in the ortolan bunting. Behav. Ecol. 16: $20-24$.

Delius, J. D. (1965) A population study of skylarks Alauda arvensis. Ibis 107: 466-492.

De Juana, E., Suárez, F., Ryan, P., Alström, P. and Donald, P. (2004) Family Alaudidae (Larks). Pp. 496-601 in J. Del Hoyo, A. Elliott and D. A. Christie, eds. Handbook of the birds of the world. Vol. 9. Cotingas to pipits and wagtails. Barcelona, Spain: Lynx Edicions.

García, J. T., Suárez, F., Garza, V., CaleroRiestra, M., Hernández, J. and Pérez-Tris, J. (2008) Genetic and phenotypic variation among geographically isolated populations of the globally threatened Dupont's lark Chersophilus duponti. Mol. Phylogenet. Evol. 46: 237-251.

García-Antón, A., Garza, V. and Traba, J. (2015) Dispersión de más de $30 \mathrm{~km}$ en un macho de primer año de alondra ricotí (Chersophilus duponti) en el Sistema Ibérico. I Workshop Nacional de la Alondra ricotí Chersophilus duponti: Estrategias Futuras. Estación Ornitológica de Padul, Granada, 13 junio 2015.

Garza, V., Suárez, F., Herranz, J., Traba, J., García de la Morena, E. L., Morales, M. B., González, R. and Castañeda, M. (2005) Home range, territoriality and habitat selection by the Dupont's lark Chersophilus duponti during the breeding 
and postbreeding periods. Ardeola 52: 133-146.

Gómez-Catasús, J., Pérez-Granados, C., Barrero, A., Bota, G., Giralt, D., López-Iborra, G. M., Serrano, D. and Traba, J. (2018) European population trends and current conservation status of an endangered steppe-bird species: the Dupont's lark Chersophilus duponti. PeerJ 6: e5627.

Greenwood, P. J. (1980) Mating systems, philopatry, and dispersal in birds and mammals. Anim. Behav. 28: 1140-1162.

Greenwood, P. J. and Harvey, P. H. (1982). The natal and breeding dispersal of birds. Ann. Rev. Ecol. Syst. 13: 1-21.

Laiolo, P. and Tella, J. L. (2007) Erosion of animal cultures in fragmented landscapes. Front. Ecol. Environm. 5: 68-72.

Laiolo, P., Vögeli, M., Serrano, D. and Tella, J. L. (2007) Testing acoustic versus physical marking: two complementary methods for individual-based monitoring of elusive species. J. Avian Biol. 38: 672-681.

Legrand, D., Cote, J., Fronhofer, E. A., Holt, R. D., Ronce, O., Schtickzelle, N., Travis, J. M. J. and Clobert, J. (2017) Eco-evolutionary dynamics in fragmented landscapes. Ecography 40: 9-25.

Lidicker, W. Z. Jr. (1975) The role of dispersal in the demography of small mammals. Pp. 103-128 in K. Petrusewicz, E. B. Golley and L. Ryszkowski, eds. Small mammals: productivity and dynamics of populations. London, UK: Cambridge University Press.

Matthysen, E. (2005) Density-dependent dispersal in birds and mammals. Ecography 28: 403-416.

Méndez, M., Tella, J. L and Godoy, J. A. (2011) Restricted gene flow and genetic drift in recently fragmented populations of an endangered steppe bird. Biol. Conserv. 144: 2615-2622.

Moreno, J. (2016) The unknown life of floaters: The hidden face of sexual selection. Ardeola 63: 49-77.

Naef-Daenzer, B., Widmer, F. and Nuber, M. (2001) Differential post-fledging survival of great and coal tits in relation to their condition and fledging date. J. Anim. Ecol. 70: $730-738$.

Nathan, R., Klein, E., Robledo-Arnuncio, J. J. and Revilla, E. (2012) Dispersal kernels: review. Pp. 187-210 in J. Clobert, M. Baguette, T. G. Benton and J. M. Bullock, eds. Dispersal ecology and evolution. Oxford, UK: Oxford University Press.

Palma, C. (2018) La colaboración a nivel local favorece el último reducto burgalés de alondra ricotí. Quercus 384: 44.

Paradis, E., Baillie, S. R., Sutherland, W. J. and Gregory, R. D. (1998) Patterns of natal and breeding dispersal in birds. J. Anim. Ecol. 67: 518-536.

Penteriani, V., Ferrer, M. and Delgado, M. D. M. (2011) Floater strategies and dynamics in birds, and their importance in conservation biology: towards an understanding of nonbreeders in avian populations. Anim. Conserv. 14: 233-241.

Pérez-Granados, C. and López-Iborra, G. M. (2013) Census of breeding birds and population trends of the Dupont's Lark Chersophilus duponti in Eastern Spain. Ardeola 60: 143-150.

Pérez-Granados, C. and López-Iborra, G. M. (2015) Nest failure owing to intraspecific agonistic behaviour in Dupont's Lark Chersophilus duponti. Ornithol. Sci. 14: 117-121.

Pérez-Granados, C. and López-Iborra, G. M. (2017) Assessment of counting methods used for estimating the number of territorial males in the endangered Dupont's Lark. Ardeola 64: 75-84.

Pérez-Granados, C. and Traba, J. (2019) Testing the conspecific attraction hypothesis with Dupont's Larks, a resident species of songbird in central Spain. J. Field Ornithol. 90: $277-285$.

Pérez-Granados, C., Lopez-Iborra, G. M. and Seoane, J. (2017a) A multi-scale analysis of habitat selection in peripheral populations of the endangered Dupont's Lark Chersophilus duponti. Bird Conserv. Internatn. 27: 398-413.

Pérez-Granados, C., López-Iborra, G. M., Garza, V. and Traba, J. (2017b) Breeding biology of the endangered Dupont's Lark Chersophilus duponti in two separate Spanish shrub-steppes. Bird Study 64: 328-338.

R Development Core Team. (2017) R: A language and environment for statistical computing, version R-3.4.1. Vienna, Austria: $\mathrm{R}$ Foundation for Statistical Computing. 
Sáez-Gómez, P., Pérez-Granados, C. and López-Iborra, G. M. (2019) Estudios aplicados a la conservación de las poblaciones de alondra ricotí (Chersophilus duponti) en el entorno del municipio de Vallanca. Informe IX. Instituto Multidisciplinar para el Estudio del Medio Ramón Margalef. Universidad de Alicante. Generalitat Valenciana. Unpublished report.

Shitikov, D., Grudinskaya, V., Makarova, T., Vaytina, T., Fedotova, S., Samsonov, S. and Grabovsky, A. (2020) Low first-year apparent survival of passerines in abandoned fields in northwestern Russia. The Condor 122(5): duaaoo8.

Suárez, F., ed. (2010) La alondra ricotí, Chersophilus duponti. Madrid, Spain: Dirección General para la Biodiversidad. Ministerio de Medio Ambiente y Medios Rural y Marino.

Suárez, F., García, J. T., Sampietro, F. J. and Garza, V. (2006). The non-breeding distribution of Dupont's Lark Chersophilus duponti in Spain. Bird Conserv. Internatn. 16: 317-323.

Suárez, F., García, J. T., Carriles, E., Calero, M., Agirre, A., Justribó, J. H. and Garza, V. (2009) Sex-ratios of an endangered lark after controlling for a male-biased sampling. Ardeola 56: 113-118.

Svensson, L. (1992) Identification guide to European passerines. $4^{\text {th }}$ edition. Stockholm, Sweden: L. Svensson.

Taylor, L. R. and Taylor, R. A. (1977) Aggregation, migration and population mechanics. Nature 265: 415-421.

Vögeli, M., Serrano, D., Tella, J. L., Méndez, M. and Godoy, J. A. (2007) Sex determination of Dupont's lark Chersophilus duponti using molecular sexing and discriminant funtions. Ardeola 54: 69-79.

Vögeli, M., Laiolo, P., Serrano, D. and Tella, J. L. (2008) Who are we sampling? Apparent survival differs between methods in a secretive species. Oikos 117: 1816-1823.

Vögeli, M., Serrano, D., Pacios, F. and Tella, J. L. (2010) The relative importance of patch habitat quality and landscape attributes on a declining steppe-bird metapopulation. Biol. Conserv. 143: 1057-1067.

Wolf, A. L., Slater, G. L., Pearson, S. F., Anderson, H. E. and Moore, R. (2020) Range-wide patterns of natal and breeding dispersal in the Streaked Horned Lark. Northwest Sci. 94: $31-43$. 